\title{
Path Analysis on the Organizational Factors Affecting Medical Service Quality and Patient Satisfaction at Dr. Moewardi Hospital, Surakarta
}

\author{
Riska Rosita'), Bhisma Murti'2), Sumanto3) \\ 1)School of Medical Record APIKES Citra Medika, Surakarta \\ 2)Masters Program in Public Health, Universitas Sebelas Maret \\ 3)Faculty of Social and Political Sciences, Universitas Sebelas Maret
}

\begin{abstract}
Background: Health service quality and patients satifaction are two important determinants for a hospital competitiveness. Patients always expect that the hospital provide good quality and satisfying service. This study aimed to determine the organizational factors that affect medical service quality and patient satisfaction at Dr. Moewardi Hospital, Surakarta.

Subjects and Method: This was an analytical observational study using cross sectional design. This study was conducted at Dr. Moewardi Hospital, Surakarta, Indonesia, in November-December 2016. A total of 120 patients at Dr. Moewardi Hospital was selected by stratified random sampling. The independent variables were personnel welfare, availability of facilities, and regulation of health care. The dependent variables were the quality of inpatient medical service and patient satisfaction. The data were collected by a questionnaire and analyzed by path analysis.

Results: Personnel welfare $(b=-0.13 ; p=0.595)$ was not associated with the quality of medical service and patient satisfaction. Availability of facilities $(b=$ size was $2.82 ; p=<0.001)$ had positive effect on the quality of medical care and patient satisfaction. Path analysis showed goodness of fit of the model, with CMIN $=4.35, \mathrm{p}=0.113, \mathrm{NFI}=0.99, \mathrm{CFI}=0.99$, and RMSEA $=0.09$.

Conclusion: Personnel welfare and availability of facilities have positive effects on the quality of inpatient medical service and patient satisfaction.
\end{abstract}

Keywords: Personnel welfare, availability of facility, quality of inpatient medical service, patient satisfaction, hospital.

Correspondence:

Riska Rosita. School of Medical Record, APIKES Citra Medika, Surakarta. Email: ross_rzkrosita@yahoo.com

\section{BACKGROUND}

Measuring the medical service quality is very important to achieve patient satisfaction. Patients always expect that the hospital provide good quality and satisfying service. Therefore, hospitals need to manage good health services by always paying attention to organizational factors.

Health care organizations are organizations whose one of the goals to provide medical service quality to the community (Satrianegara, 2014). The sufficient of personnel welfare is needed to maximize existing health services. In addition, the large number of population also demands an increase in the quantity of human resources (Khariza, 2015).

Dr. Moewardi Hospital, Surakarta, is a referral hospital in eks karisidenan Surakarta which belongs to an type A public hospital. Based on a previous survey of the experience of several patients in Dr. Moewardi Hospital, patients with BPJS (Social Insurance Administration Organization) got unsatisfactory services. Some of the complaints of patients in the hospital were: (1) the complexity of administering inpatient registration, (2) the length of time 
waiting for a medical examination or intervention schedule, (3) the doctor visit schedule which is uncertain, and so on.

The community always expects that hospital services, both public and private, can provide satisfying services for people who use it. The result of a study conducted by Nadi et al. (2016) based on the level of satisfaction of inpatients analyzed through the SERVQUAL approach, in three differrent hospital locations, proves that based on five quality measures, there were patient expectations which had not been achieved. Meanwhile, the success of a hospital in carrying out its functions is marked by an increase in quality of hospital services.

This study aimed to analyze the organizational factors that affect medical service quality and patient satisfaction.

\section{SUBJECTS AND METHOD}

This study used an analytical observational study using cross sectional design. This study was conducted at Dr. Moewardi Hospital, Surakarta, in November-December 2016. There were 113,773 patients as the Table 1. Sample characteristics

\begin{tabular}{llcc}
\hline \multicolumn{1}{c}{ Criteria } & \multicolumn{1}{c}{ Classification } & Frequency & \% \\
\hline Gender & Male & 58 & 48.3 \\
Age & Female & 62 & 51.7 \\
& < 40 years & 58 & 48.3 \\
& 40-50 years & 35 & 29.2 \\
Education & 51-60 years & 19 & 15.8 \\
& > 60 years & 8 & 6.7 \\
& No education & 10 & 8.3 \\
& Elementary Schol & 16 & 13.3 \\
Payement Method & Junior High School & 30 & 25.0 \\
& Senior High School & 47 & 39.2 \\
\multirow{3}{*}{ Medical Ward } & College & & 14.2 \\
& General & 20 & 16.7 \\
& BPJS & 97 & 80.8 \\
& JAMKESDA & 3 & 2.5 \\
& Mawar II & 33 & 27.5 \\
& Mawar III & 24 & 20.0 \\
& Anggrek I & 24 & 20.0 \\
& Aster V & 9 & 7.5 \\
\hline
\end{tabular}

population of the study. A total of 120 patients as the subjects of the study were selected by stratified random sampling.

The exogenous variables were personnel welfare, availability of facilities, and regulation of health care. The endogenous variables were medical service quality and patient satisfaction. The data were collected by a set of questionnaire which previously has been tested for validity and reliability. The data were analyzed by path analysis.

\section{RESULTS}

\section{Sample characteristics}

The result of the characteristics of the subjects of the study in Table 1 shows that $51.7 \%$ of the 120 respondents of the study were female. Most of the subjects of the study were $<40$ years old by $48.3 \%$. Meanwhile, the highest education level was senior high school by $39.2 \%$. In the types of patients based on the payment method, most of the patients paid with BPJS by $80.8 \%$. Based on all subjects of the study, the highest number were patients treated in the MAWAR II medical ward by $27.5 \%$. 


\section{Path analysis}

a. Model Specification

This was the initial model in path analysis.

b. Model identification

The measurement variables were 4, the endogenous variables were 2 , the exogenous variables were 2 , the number of parameters was 4 .

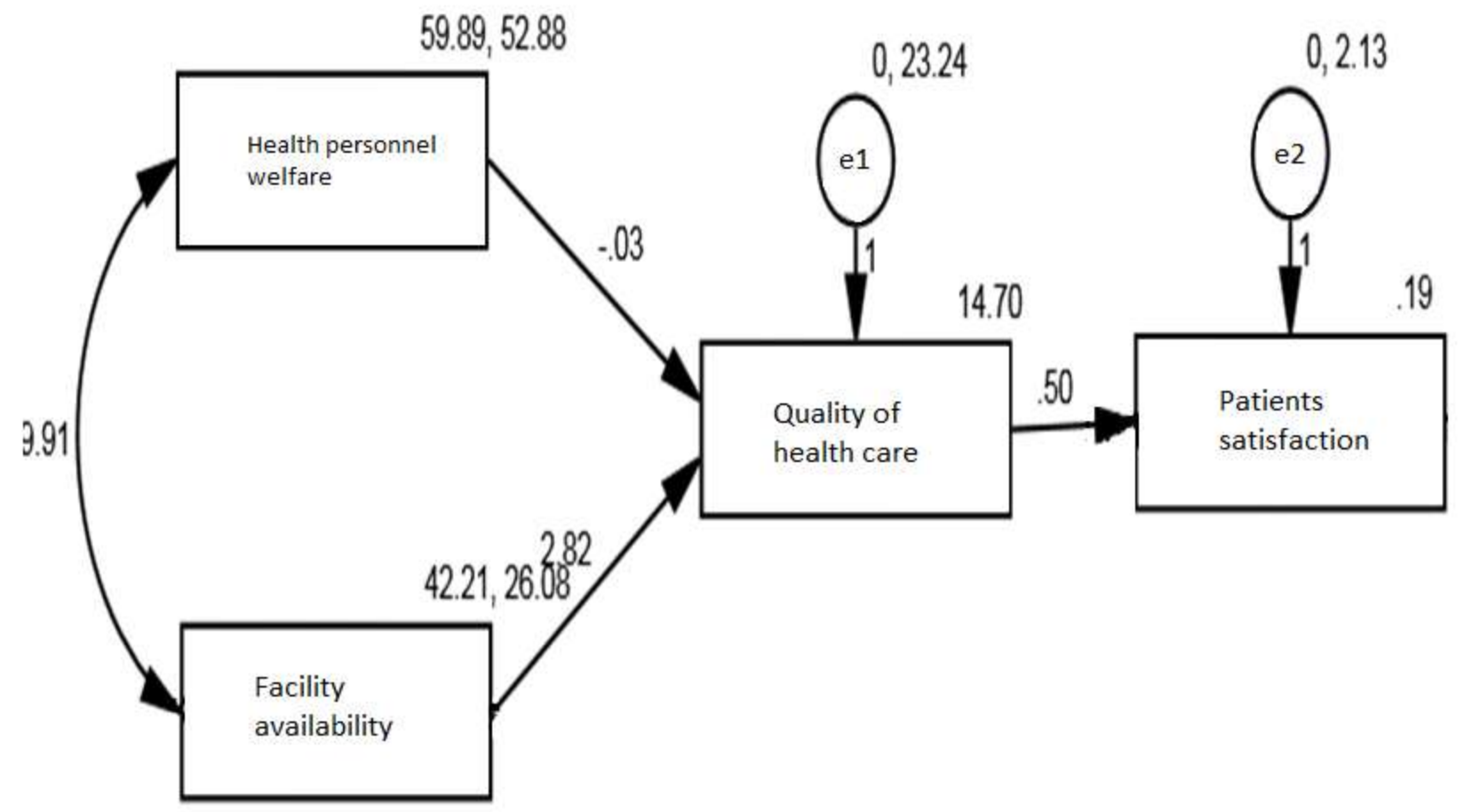

Degree of freedom $(\mathrm{df})=$ (total number of measurement variables $\mathrm{x}$ (total number of measurement variables+1) / 2 (endogenous variables+exogenous variables+number of parameters $)=(4 \times 5) / 2-(2+2+4)=2$. Model identification was over identified, which means that path analysis could be conducted.

\section{Figure 1. The structural model with unstandarized}

\section{c. Model fit}

The suitability of path analysis model made by the researchers based on theory was checked with the best variable model by computer (SPSS), namely the saturation model, which was made based on sample data collected by researchers. Figure 1 shows the structural model after estimation using IBM SPSS AMOS 22.

Based on the indicator which showed the suitability of path analysis model as in table 2 which also showed the existence of Goodness of Fit Measure, the result of CMIN fit index were 4.35 with $\mathrm{p}=0.113$; $\mathrm{NFI}=0.99(\geq 0.90) ; \mathrm{CFI}=0.99(\geq 0.90)$; RMSEA $=0.09(\geq 0.08)$. It means that the empirical model met the criteria specified and stated in accordance with empirical data.

Table 2 shows the result of calculation using IBM SPSS AMOS 22 computer software program, such as an unstandardized path coefficient value (b) the medical service quality for inpatient satisfaction was positive by 0.50 , the $\mathrm{SE}$ value $=0.01, \mathrm{p}$ $<0.001$, and the standardized path coefficient $(\beta)$ was 0.98 , which was significant. These results indicate that every unit of medical service quality would increase the inpatient satisfaction score by 0.50 .

The unstandardized path coefficient value (b) the availability of facility on 
medical service quality was positive by 0.09 , the SE value was 0.09 , the $\mathrm{p}$ value was <0.001, and the standardized path coefficient value $(\beta)$ was 0.95 ; they were

Table 2. The result of path analysis on the organizational factors affecting medical service quality and patient satisfaction

\begin{tabular}{|c|c|c|c|c|c|c|}
\hline Dependent Variable & & Independent Variable & b & SE & $\mathbf{p}$ & $\boldsymbol{\beta}$ \\
\hline Direct Effect & & & & & & \\
\hline Patient satisfaction & $\leftarrow$ & Medical service quality & 0.50 & 0.01 & $<0.001$ & 0.98 \\
\hline $\begin{array}{l}\text { Indirect Effect } \\
\text { Medical service quality }\end{array}$ & $\leftarrow$ & Availability of facility & 282 & 000 & $<0.001$ & 0.95 \\
\hline Medical service quality & $\leftarrow$ & Personnel welfare & -0.03 & 0.06 & 0.595 & $\begin{array}{r}0.95 \\
-0.02\end{array}$ \\
\hline $\mathrm{N}$ Observasi $=120$ & & & & & & \\
\hline Fit Model & & & & & & \\
\hline $\mathrm{CMIN}=4.35$ & & & & & & \\
\hline $\mathrm{p}=0.113(\geq 0.05)$ & & & & & & \\
\hline $\mathrm{NFI}=0.99(\geq 0.90)$ & & & & & & \\
\hline $\mathrm{CFI}=0.99(\geq 0.90)$ & & & & & & \\
\hline RMSEA $=0.99(\geq 0.08)$ & & & & & & \\
\hline
\end{tabular}

The unstandardized path coefficient value (b) the personnel welfare on medical service quality was negative by -0.03 , the $\mathrm{SE}$ value was 0.06 , the $\mathrm{p}$ value was 0.595 , and the standardized path coefficient value $(\beta)$ was 0.02; they were almost significant. These results indicated that each increase in one unit score of personnel welfare would decrease the medical service quality score by 0.03 .

a. Respecification Model

The model in this study was in accordance with the sample data as indicated by the saturation model and also the path coefficient which were more than zero and statistically significant, so that there was no need to make a path analysis model.

\section{DISCUSSION}

\section{The effect of personnel welfare on patient satisfaction level through medical service quality as the intervening variable}

There was an indirect effect of personnel welfare on patient satisfaction level through medical service quality as the intervening variable. As a result, personnel welfare significant. These results indicated that each increase in one unit score of availability of facility would increase the medical service quality score by 2.82 . almost affected medical service quality but statistically non-significant.

This study was not in accordance with a study conducted by Suwati (2013) which stated that variable pay partially had a positive and significant effect on employee performance at PT. Tunas Hijau Samarinda, so that an increase in compensation would improve employee performance.

In this study, the workload of nurses at Dr. Moewardi Hospital, Surakarta, was very high. The ratio of nurses to patients has not met the standards. Some nurses complained of work fatigue in serving patients. According to a study condcuted by Kurniawati and Sholihah (2012), there is a correlation between work fatigue and the nurses performance in the inpatient ward of the Fatimah Islamic Hospital, Cilacap.

Based on the result of the observation on statistical report of hospitalization in each ward, the number of Bed Occupancy Ratio (BOR) in Melati III ward exceeded the Department of Health RI standards. It shows a high level of utilization of the bed which causes the quality of the medical team's performance decreases. 
Based on the explanation above,the quality of service is not only determined by job satisfaction, but it also affected by employee performance. This is supported by a study conducted by Terry and Israel (2004) which state that employee performance is the factor which can affect the quality of service to consumers, so that consumers feel satisfied. According to Indrawati (2013), good management of employee performance is able to increase the patients satisfaction in the hospital.

Based on the explanation above, it can be concluded that there is an indirect negative correlation between personnel welfare and patient satisfaction level through medical service quality. In order to improve the medical service quality, the personnel performance quality in providing services to patients needs to be maintained.

\section{The effect of availibility of facility on patient satisfaction level through medical service quality as the intervening variable}

There was an indirect effect of avalibility of facility on patient satisfaction level through medical service quality as the intervening variable. The effect was positive and significant. As a result, personnel welfare almost affected medical service quality but statistically non-significant. The availability of facility which is more adequate will affect on the better medical service quality and the patient satisfaction level which is increase.

The result of this study is relevant to a study conducted by Mongkaren (2013) which shows that facility and quality of services simultaneously and partially have a significant effect on customer satisfaction. This is supported by Utama (2003) which states that the result of regression analysis indicates that physical evidence variables have a significant effect on customer satisfaction. It shows that customer satisfaction (patients) is affected by perceptions of the quality of services, which was seen from the dimensions of tangibles such as physical facilities and medical equipment.

The result of this study is also relevant to a study conducted by Supriyanto (2012) which shows that quality of services, price and hospital facilities have a positive and significant effect on patient satisfaction in Kariadi Hospital Semarang.

Based on the explanation above, it can be concluded that there is an indirect positive correlation between availability of facility and inpatients satisfaction level through medical service quality. Therefore, the result of this study is in accordance with previous study and existing theories.

\section{The effect of medical service qua- lity on inpatients satisfaction level}

There was a direct effect of medical service quality on inpatient satisfaction level. The effect was positive and significant. The better medical service quality will increase the inpatient satisfaction level.

The result of this study is in accordance with a study conducted by Mustofa (2008), which proves that there is a significant correlation between nursing service quality and patient. Nursing is the main basis of services in hospitals. For 24 hours, nurses are always near the patient, so that the nurse plays a dominant role in giving satisfaction to inpatients.

This study is relevant to a study conducted by Utama (2003) which proves that the medical service quality has a very strong influence on patient satisfaction at the Cakra Husada Hospital, Klaten.

Based on the explanation above, it can be concluded that there is a direct positive correlation between medical service quality and inpatients satisfaction level. The better medical service quality will increase the inpatient satisfaction level. Therefore, the 
result of this study is in accordance with previous study.

\section{REFERENCE}

Indrawati AD (2013). Pengaruh Kepuasan Kerja terhadap Kinerja Karyawan dan Kepuasan Pelanggan pada Rumah Sakit Swasta di Kota Denpasar. Jurnal Manajemen, Strategi Bisnis, dan Kewirausahaan. $7(2)$.

Khariza HA (2015). Program Jaminan Kesehatan Nasional: Studi Deskriptif tentang Faktor-faktor yang Dapat Mempengaruhi Keberhasilan Implementasi Program Jaminan Kesehatan Nasional di Rumah Sakit Jiwa Menur Surabaya. Jurnal Kebijakan dan Manajemen Publik. 3(1).

Kurniawati S (2012). Hubungan Kelelahan Kerja dengan Kinerja Perawat di Bangsal Rawat Inap Rumah Sakit Islam Fatimah Kabupaten Cilacap. KESMAS. 6(2: 162-232.

Mongkaren S (2013). Fasilitas dan Kualitas Pelayanan Pengaruhnya terhadap Kepuasan Penguna Jasa Rumah Sakit Advent Manado. Jurnal EMBA. 1(4): 493-503.
Mustofa A (2008). Hubungan antara Persepsi Pasien terhadap Dimensi Mutu Pelayanan Keperawatan dengan Kepuasan Pasien di Ruang Rawat Inap Rumah Sakit Umum PKU Muhammadiyah Temanggung. Jurnal Keperawatan. 1(2).

Satrianegara F (2014). Organisasi dan Manajemen Pelayanan Kesehatan. Jakarta: Salemba Medika.

Supriyanto Y (2012). Kepuasan Pasien Rawat Jalan di Rumah Sakit Kariadi Semarang. Skripsi. Semarang: UNDIP Press.

Suwati Y (2013). Pengaruh Kompensasi dan Motivasi Kerja terhadap Kinerja Karyawan pada PT. Tunas Hijau Samarinda. Jurnal Ilmu Administrasi Bisnis. 1(1).

Terry BD, Israel GD (2004). Agent Performance and Customer Satisfaction. Journal of Extension. 42(6).

Utama A (2003). Analisis Pengaruh Persepsi Kualitas Pelayanan terhadap Kepuasan Pelanggan Rumah Sakit Umum Cakra Husada Klaten. Jurnal OPSI. 1(2): 96-110. 